Journal of Reproduction and Development, Vol. 46, No. 3, 2000

\title{
Modulatory Action of Nitric Oxide on the Expression of Transcription Factor Genes, c-fos and c-jun, in Developing Porcine Granulosa Cells In Vitro
}

\author{
Norichika NISHIDA, Katsuhisa TAKESUE, Masa-aki HATTORI, \\ Yukio KATO'), Katsumi WAKABAYASHI') and Noboru FUJIHARA
}

\author{
Laboratory of Reproductive Physiology, Graduate School of Bioresource and \\ Bioenvironmental Sciences, Kyushu University, Hakozaki, Fukuoka 812-8581, and \\ 1) Biosignal Research Center, Institute for Molecular and Cellular Regulation, Gunma \\ University, Maebashi 371-8512, Japan
}

\begin{abstract}
The present study was performed to clarify the synthesis of nitric oxide (NO) and its effect on the expression of transcription factor genes (c-fos, c-jun and ATF-4) during the differentiation of granulosa cells. Granulosa cells prepared from porcine ovarian follicles (1-4 mm diameter) were matured with FSH for $48 \mathrm{~h}$. From $40 \mathrm{~h}$ to $48 \mathrm{~h}$ of ovine FSH stimulation, nitrite and nitrate increased by 2 folds, and this was accompanied by an increase of cyclic GMP. The cells were exposed to either NO scavenger (carboxy-PTIO: 2-(4-carboxyphenyl)-4,4,5,5tetramethylimidazoline-1-oxy-3-oxide) or NO donor (NOC18: 2,2'-(hydroxynitrosohydrazino)bisethanamine) before or after NO generation, and further stimulated with ovine LH until $48 \mathrm{~h}$ Removal of endogenous NO (NO scavenger) induced a serious impairment in the LH-induced synthesis of progesterone, whereas NO donor had no significant effect on the synthesis. In the semi-quantitative reverse transcriptase-PCR of the transcription factor mRNAs, removal of endogenous NO resulted in a reduction of c-fos expression, an increase of c-jun and no changes in ATF-4 expression. In contrast, NO donor had no significant effects on the expression of these transcription factor genes. Consequently, the transient generation of NO may have critical roles in the LH-induced expression of transcription factor genes and thereafter transformation of the granulosa cell to the luteal cell.

Key words: Nitric oxide, Transcription factor genes, Granulosa cell differentiation.
\end{abstract}

(J. Reprod. Dev. 46: 167-175, 2000)

$\mathbf{N}$

itric oxide $(\mathrm{NO})$ is a short-lived messenger molecule that mediates a variety of cellular functions. $\mathrm{NO}$ is generated from molecular $\mathrm{O}_{2}$ and L-arginine by nitric oxide synthase (NOS) [1-4]. Constitutive isoforms such as endothelial (eNOS) and neural NO (nNOS) synthases [5, 6], and an inducible isoform (iNOS) [7] have been identified.

Accepted for publication: March 3, 2000

Correspondence: M-A. Hattori
The expression of mRNAs and proteins for eNOS and iNOS in the rat ovary has been shown during follicular development, ovulation and pseudopregnancy $[8,9]$. In rat and human ovarian cells, NO has been shown to be involved in folliculogenesis, ovulation and steroidogenesis [1015]. In our previous study using rat granulosa cells [16], NO was proposed as functioning as a modulator in cell differentiation, because removal of NO during cell differentiation suppressed 
expression of the EGF receptor. In contrast, NO has been reported to inhibit steroidogenesis in rat, human and porcine ovarian cells [17-20].

FSH induces the transformation from immature to mature granulosa cells, then the mature cells are further transformed into luteinized cells by LH. The process of cell differentiation is generally accepted to be mediated by the cyclic AMP signaling pathway [21]. Protein kinase $C$ is also an essential element in the expression of genes during the differentiation of granulosa cells [22]. The differentiation process is also accompanied by the expression of several proto-oncogenes in many cell types. The transient or constitutive expression of the transcription factors such as proto-oncogenes (c-fos, c-jun, c-myc), and the cyclic AMP response element binding protein (CREB or ATF-4) family is promoted by protein kinase $\mathrm{C}$ and/or protein kinase A $[23,24]$. The major actions of such transcription factors are related to the transcription of several late gene responses that are regulators of cell differentiation. Consequently, we raised the interesting possibility of NO participation in the expression of the transcription factors. In this study using porcine granulosa cells, we investigated NO modulation in the expression of c-fos, c-jun and ATF-4 by a semi-quantitative reverse transcriptase (RT)-PCR.

\section{Materials and Methods}

\section{Materials}

Ovine FSH (NIDDK-oFSH-20) and LH (NIDDKoLH-26) were supplied by Dr. A. F. Parlow (Harbor-UCLA Medical Center, Torrance, CA, USA). Ham's F-10 and DMEM were obtained from GIBCO Laboratories (Grand Island, NY, USA). 2-(4-carboxy pheny 1)-4, 4, 5, 5-tetramethylimidazoline-1-oxy-3-oxide (carboxy-PTIO) 2,2'(hydroxynitrosohydrazino)bis-ethanamine (NOC18) and S-nitroso-N-acetyl-DL-penicillamine (SNAP) were obtained from Dojindo (Kumamoto, Japan). Sodium pentacyanonitrosylferrate(III)dihydrate (SNP) was obtained from Nacalai Tesque (Kyoto, Japan); ISOGEN from Wako (Osaka, Japan), T-primed first-strand kit from Amersham Pharmacia Biotech (Tokyo, Japan), and AmpliTaq Gold polymerase from Perkin-Elmer (Norwalk, CT, USA). All the other chemicals used were of reagent grade and obtained from commercial sources.

\section{Cell culture}

The porcine ovaries were obtained at a local slaughterhouse. Granulosa cells were prepared from small-sized (1-4 $\mathrm{mm}$ diameter) follicles by aspirating with a 20-gauge needle and then filtering through a fine stainless mesh. They were treated with $50 \mu \mathrm{g} / \mathrm{ml}$ DNase I at $37 \mathrm{C}$ for $5 \mathrm{~min}$, and washed with Ham's F10 and DMEM (1:1) supplemented with $10 \mathrm{mM}$ HEPES, $50 \mu \mathrm{g} / \mathrm{ml}$ gentamycin, $20 \mathrm{U} / \mathrm{ml}$ nystatin [25]. Cell viability was determined to be $>95 \%$ by trypan blue exclusion. The cells were seeded at $2 \times 10^{5} /$ well in 48 -well plates or at $10^{6} /$ dish in $35 \mathrm{~mm}$ dishes coated with fibronectin (Becton-Dickinson, Oxnard, CA, USA) and cultured for $24 \mathrm{~h}$ with $110 \mathrm{nM}$ hydrocortisone, $1 \mu \mathrm{g} / \mathrm{ml}$ insulin, $5 \mu \mathrm{g} / \mathrm{ml}$ transferrin and $0.1 \%(\mathrm{w} / \mathrm{v})$ bovine serum albumin at $39 \mathrm{C}$ in humidified $95 \%$ air $5 \% \mathrm{CO}_{2} . \mathrm{FSH}$ was then added to the cultures (culture 0 day), and the cells were matured by culture for an additional 48 $\mathrm{h}$ before washing and exposure to LH. CarboxyPTIO, SNAP, and SNP were dissolved in culture medium and added to cultures at $30 \mathrm{~h}$ and $46 \mathrm{~h}$ after the start of culture. NOC18 was dissolved in $0.1 \mathrm{M} \mathrm{NaOH}$ which was adjusted to $\mathrm{pH}$ 7.2-7.5 with $50 \mathrm{mM}$ Tris- $\mathrm{HCl}(\mathrm{pH} \mathrm{7.0)}$, and added to cultures at the same times.

\section{Measurements of nitrite and nitrate}

Medium samples were collected at indicated times. After the removal of proteins from the cultured media with 50\% methanol, soluble fractions were analyzed with an automated NO detector HPLC system (ENO-20, EICOM, Kyoto, Japan) [26]. Nitrite and nitrate were separated by a reverse phase separation column packed with polystyrene polymer, and nitrate was reduced to nitrite with copper-plated cadmium filings. Nitrite was mixed with a Griess reagent to form a purple azo dye in a reaction coil. The mobile phase was $10 \%$ methanol containing $0.15 \mathrm{M} \mathrm{NaCl} / \mathrm{NH}_{4} \mathrm{Cl}$ and $0.5 \mathrm{~g} / 1 \mathrm{EDTA}-4 \mathrm{Na}$, and the flow rate was $0.33 \mathrm{ml} /$ min. The absorbance of the product dye was measured at $540 \mathrm{~nm}$ by a flow-through spectrophotometer. Medium cultured without cells was used as a blank for measurements of nitrite and nitrate.

\section{RNA isolation and $c D N A$ preparation}

After removing the media, ISOGEN was added 
to each well to dissolve the cells $\left(10^{6}\right)$. Each resulting solution was extracted with chloroform and centrifuged at $12000 \times \mathrm{g}$ for $15 \mathrm{~min}$. The aqueous phase was collected and precipitated with isopropylalcohol at room temperature, and the precipitate was washed with $75 \%(\mathrm{v} / \mathrm{v})$ ethanol. After drying, the recovered RNA was dissolved in $20 \mu$ l diethylpyrocarbamate-treated water. The reverse transcription was performed using a Tprimed first-strand kit as follows: $10 \mu \mathrm{l}$ RNA samples mixed with the reagent were incubated at $37 \mathrm{C}$ for $1 \mathrm{~h}$, after which diethylpyrocarbamatetreated water was added to each tube (final volume, $50 \mu \mathrm{l})$, and the mixture heated at $70 \mathrm{C}$ for $5 \mathrm{~min}$.

Analysis of granulosa cells for mRNA of c-fos, cjun and ATF-4 using reverse transcriptase-PCR (RT-PCR)

RT-PCR was performed on total RNA using a Program Temp Control system PC-800 (ASTEC, Fukuoka, Japan). The oligonucleotides specific for c-fos [27], c-jun [27], ATF-4 [28] and $\beta$-actin [29] were synthesized by Hokkaido System Science (Sapporo, Japan). The sequences of these oligonucleotides are described in Table 1. A mouse $\beta$-actin cDNA fragment was selected as a control. Amplification of each cDNA ( $1 \mu \mathrm{l}$ of RT template) was performed in $10 \mu \mathrm{l}$ of $1 \times$ PCR buffer, $0.2 \mathrm{mM}$ dNTPs, 0.25 U AmpliTaq Gold polymerase, and $0.2 \mu \mathrm{M}$ each of the synthetic primers. After an initial denaturation step ( $95 \mathrm{C}$ for $9 \mathrm{~min}$ ), the amplification step for porcine c-fos, c-jun and ATF4 consisted of 35 cycles under a thermal profile of $95 \mathrm{C}$ for $30 \mathrm{sec}$ (denaturation), $54 \mathrm{C}$ for $30 \mathrm{sec}$ (annealing), and $72 \mathrm{C}$ for $2 \mathrm{~min}$ (synthesis). The products were resolved on a $2 \%(\mathrm{w} / \mathrm{v})$ agarose/
TBE gel containing ethidium bromide, and quantified as a reference gene of $\beta$-actin using a densitometry program (NIH image Ver. 1.58).

Assays of cyclic nucleotides and progesterone

Medium samples were collected at indicated time, heated and succinylated. Cyclic nucleotides were determined by specific radioimmunoassays [30] and calculated with the use of a competitive assay computer program. There was $0.07 \%$ cyclic GMP cross-reactivity with the cyclic AMP antiserum and $0.15 \%$ cyclic AMP cross-reactivity with the cyclic GMP antiserum. The lower limits of detection for both assays were $0.09 \mathrm{pmol} / \mathrm{ml}$, and the intra-assay and inter-assay variabilities were $<10 \%$. In some experiments, medium samples collected were diluted with assay buffer and determined for progesterone using an enzyme immunoassay kit (Cayman Chemical Co., Ann Arbor, MI, USA). The detection limit was 10 pg/ $\mathrm{ml}$, and the intra-assay and inter-assay variabilities were $<10 \%$.

\section{Statistical analysis}

The data are expressed as means $\pm \mathrm{SE}$; differences between them were analyzed using Student's ttest following analysis of variance.

\section{Results}

Cyclic GMP formation and NO synthesis during development

$\mathrm{LH}$ receptor mRNA was expressed $24 \mathrm{~h}$ after FSH stimulation of porcine granulosa cells, as revealed by RT-PCR (data not shown). Thereafter,

Table 1. Oligonucleotide primers used for PCR analysis

\begin{tabular}{|c|c|c|c|}
\hline mRNA & Sequences & $\begin{array}{c}\text { Nucleotide } \\
\text { number }\end{array}$ & $\begin{array}{l}\text { Expected PCR } \\
\text { fragment }(b p)\end{array}$ \\
\hline \multirow[t]{2}{*}{ c-fos } & Sense: 5'-CCGAAGGGAAAGGAATAAGATGG-3' & $551-573$ & \multirow[t]{2}{*}{232} \\
\hline & Antisense: 5'-TCGGTGTCTGTAGAGAAGACC-3' & $782-762$ & \\
\hline \multirow[t]{2}{*}{ c-jun } & Sense: 5'-CGGAAAAGGAAGCTGGAGAGGATC-3' & $998-1021$ & \multirow[t]{2}{*}{179} \\
\hline & Antisense: 5'-ACGTTGACGACGCAATCGTAC-3' & $1176-1156$ & \\
\hline \multirow[t]{2}{*}{ ATF-4 } & Sense: 5'-GCAGAGCAGGAGGCCCTCACTG-3' & $1126-1147$ & \multirow[t]{2}{*}{216} \\
\hline & Antisense: 5'-CATTTGTGTGTCGATTTCGGGATCGG-3' & $1341-1316$ & \\
\hline \multirow[t]{2}{*}{$\beta$-actin } & Sense: 5'-TT(CT)TACAA(TC)GAGCTGCGTGTGG-3' & $348-369$ & \multirow[t]{2}{*}{113} \\
\hline & Antisense: 5'-AA(CG)GTCTC(GA)AACATGATCTGGGTC-3' & $460-437$ & \\
\hline
\end{tabular}


an increase of cyclic GMP level was observed $48 \mathrm{~h}$ after FSH stimulation (Fig. 1). Nitrite and nitrate were measured using an automated NO detectorHPLC system. The concentrations of nitrite and nitrate were relatively constant until $42 \mathrm{~h}$, after which they significantly increased, by 2 folds at 48 $\mathrm{h}(\mathrm{P}<0.05)$. These results indicate that $\mathrm{NO}$ synthesis is transiently promoted $42-48 \mathrm{~h}$ after $\mathrm{FSH}$ stimulation and $\mathrm{NO}$ in turn stimulates guanylate cyclase.

Effect of NO scavenger or NO donor on the cellular functions

In order to assess the role of endogenous $\mathrm{NO}$ in the functions of granulosa cells, the cells were treated with either carboxy-PTIO, a potent antagonist of $\mathrm{NO}$ action [31], or three types of $\mathrm{NO}$ donors (NOC18, SNAP and SNP). NOC18 $(50 \mu \mathrm{M})$ caused a marked increase in cyclic GMP synthesis during $5 \mathrm{~h}$ incubation with the cells in the presence of $0.1 \mathrm{mM}$ 3-isobutyl-1-methylxanthine, as compared to other NO donors (Fig. 2). NOC18 automatically produced $\mathrm{NO}$ in a short time and the cells were permeable to NO in this condition.

The effects of carboxy-PTIO or NOC18 were investigated on cyclic AMP formation and progesterone synthesis induced by LH. CarboxyPTIO $(200 \mu \mathrm{M})$ was added to cultures before NO generation $(30 \mathrm{~h})$, and the cells were further cultured until $48 \mathrm{~h}$. Then the cells were washed twice with culture medium, and stimulated with LH for $60 \mathrm{~min}$. As shown in Table 2, cyclic AMP formation decreased by $50 \%$ compared with the control. When carboxy-PTIO was added after NO generation $(46 \mathrm{~h})$, however, it had little effect on LH-induced cyclic AMP formation. In contrast to carboxy-PTIO, NOC18 $(50 \mu \mathrm{M})$ caused no significant effect on LH-induced cyclic AMP formation. In addition, progesterone was measured after 48 h stimulation with LH. When carboxyPTIO was added before NO generation, progesterone was decreased by $60 \%$ (Table 1 ). However, progesterone synthesis was not significantly influenced in the other groups. These data suggest that the removal of endogenous $\mathrm{NO}$ results in serious impairment to the functions of developing granulosa cells.

Effect of NO scavenger on the levels of c-fos, c-jun and ATF-4 mRNAs

After maturation of the granulosa cells induced

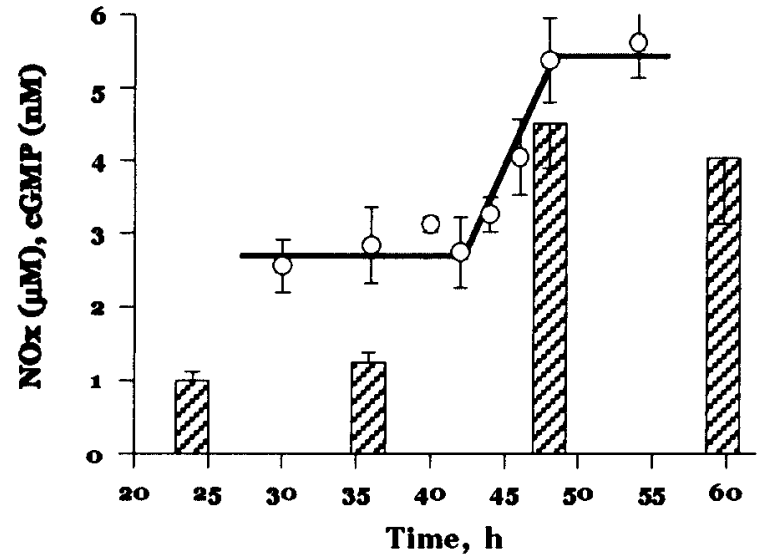

Fig. 1. Changes of cyclic GMP and NO metabolites (nitrite and nitrate) levels during differentiation of porcine granulosa cells. Granulosa cells were cultured for the indicated times with FSH $(0.3 \mathrm{ng} / \mathrm{ml})$, and then media were removed for cyclic GMP determination by a specific radioimmunoassay (column). For measurement of NO metabolites (circle), cells and media were collected together. After removal of proteins with $50 \%$ methanol, soluble fractions were analyzed with an automated NO detector HPLC system as described in Materials and Methods. Data are the means \pm S.E. of three independent experiments.

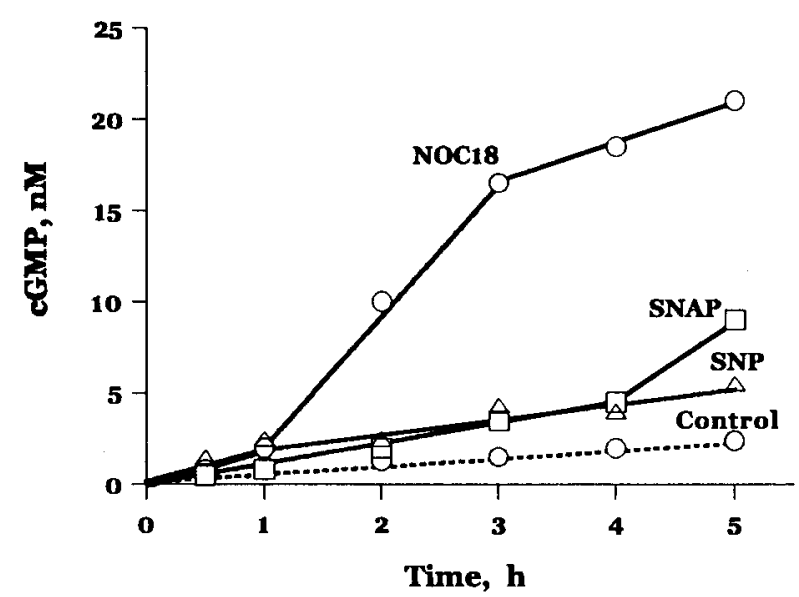

Fig. 2. Effect of NO donors on cyclic GMP accumulation by porcine granulosa cells. Granulosa cells were cultured for the indicated times with $50 \mu \mathrm{M}$ NO donors (NOC18, SNAP, SNP) in the presence of FSH $(0.3 \mathrm{ng} / \mathrm{ml})$ and $0.1 \mathrm{mM}$ 3-isobutyl-1methylxanthine, and then media were removed for cyclic GMP determination by a specific radioimmunoassay. Data are the means from closely agreeing duplicate experiments. 
Table 2. Cyclic AMP formation and progesterone synthesis in porcine granulosa cells stimulated with $\mathrm{LH}$

\begin{tabular}{lccl}
\hline Addition & $\begin{array}{c}\text { Time } \\
\text { of addition }\end{array}$ & $\begin{array}{c}\text { cAMP } \\
\mathrm{pmol} / \mathrm{ml}\end{array}$ & $\begin{array}{c}\text { Progesterone } \\
\mathrm{ng} / \mathrm{ml}\end{array}$ \\
\hline Non & - & $17.5 \pm 2.1(100)$ & $40.5 \pm 1.2(100)$ \\
carboxy-PTIO & $30 \mathrm{~h}$ & $8.4 \pm 1.4(48)^{*}$ & $24.9 \pm 0.8(61)^{* *}$ \\
carboxy-PTIO & $46 \mathrm{~h}$ & $12.7 \pm 0.8(73)$ & $43.3 \pm 1.1(107)$ \\
NOC18 & $30 \mathrm{~h}$ & $23.4 \pm 0.8(134)$ & $40.2 \pm 0.8(99)$ \\
NOC18 & $46 \mathrm{~h}$ & $12.4 \pm 0.2(71)$ & $42.7 \pm 0.5(105)$ \\
\hline
\end{tabular}

${ }^{*} \mathrm{P}<0.05$ vs control (non treatment), ${ }^{* *} \mathrm{P}<0.01$ vs control.

The porcine granulosa cells $\left(2 \times 10^{5} /\right.$ well $)$ were cultured with FSH $(0.3 \mathrm{ng} / \mathrm{ml}) ; 200$ $\mu \mathrm{M}$ 2-(4-carboxyphenyl)-4,4,5,5-tetramethylimidazoline-1-oxy-3-oxide (carboxy-PTIO) or $50 \mu \mathrm{M}$ 2,2'-(hydroxynitrosohydrazino)bis-ethanamine (NOC18) was then added to cultures at $30 \mathrm{~h}$ or $46 \mathrm{~h}$ of culture, and cells were cultured until $48 \mathrm{~h}$. Thereafter, the cells were washed and challenged for $60 \mathrm{~min}$ with $\mathrm{LH}(100 \mathrm{ng} / \mathrm{ml})$ in the presence of $0.1 \mathrm{mM} 3$-isobutyl-1-methylxanthin (IBMX), then the media were removed for cAMP assay. In the progesterone assay, the cells were challenged for 48 $\mathrm{h}$ with $\mathrm{LH}(100 \mathrm{ng} / \mathrm{ml})$ without IBMX, after which the media were removed for progesterone assay. The data are means \pm S.E. of four experiments. Values in parentheses represent percentages of the respective control value (non treatment).
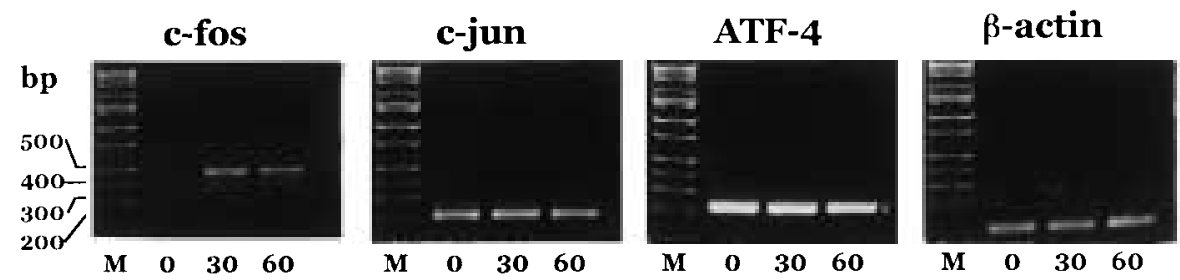

Time after LH stimulation, min

Fig. 3. Time dependent changes in the levels of transcription factors c-fos, c-jun and ATF4 mRNAs in mature granulosa cells in response to LH. The porcine granulosa cells $\left(10^{6} /\right.$ dish $)$ were cultured with FSH $(0.3 \mathrm{ng} / \mathrm{ml})$ for $48 \mathrm{~h}$, then the cells were stimulated with LH $(100 \mathrm{ng} / \mathrm{ml})$ for 30 or $60 \mathrm{~min}$. Total RNA samples were prepared and analyzed by RT-PCR, as described in Materials and Methods.

by FSH, LH-induced expressions of c-fos, c-jun and ATF-4 mRNAs were tested. A maximal expression of c-fos was observed $30 \mathrm{~min}$ after exposure to $\mathrm{LH}$, whereas c-jun and ATF-4 were consistently expressed (Fig. 3). Fig. 4 shows the effect of carboxy-PTIO pretreatment on the levels of c-fos, c-jun and ATF-4 mRNAs. When carboxy-PTIO was added before NO generation, LH-induced expression of c-fos mRNA was decreased to about $50 \%$ of the control. In contrast, the c-jun mRNA expression was increased by about $250 \%$, and no significant changes were observed in ATF-4 mRNA expression. When carboxy-PTIO was added after NO generation, however, no significant changes were observed in LH-induced expression of c-fos, c-jun and ATF-4 mRNAs.
Effect of NO donor on the levels of c-fos, c-jun and ATF-4 mRNAs

In order to compare with the effect of endogenous $\mathrm{NO}$, we next tested the effect of NOC18 pretreatment on LH-induced expression of c-fos, c-jun and ATF-4 mRNAs. NOC18 was also added to cultures before or after NO generation, which were stimulated with $\mathrm{LH}$. In contrast to carboxy-PTIO, no changes were observed in the expression of these transcription factors' mRNAs (Fig. 5).

\section{Discussion}

In this study, we investigated NO synthesis and 


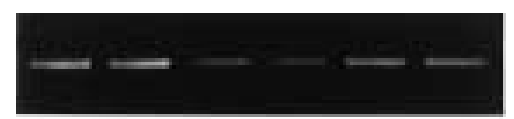

\section{c-fos}

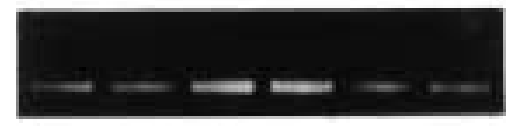

c-jun

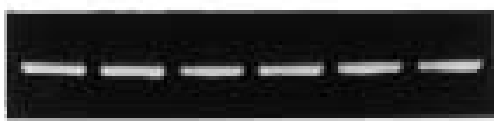

ATF-4

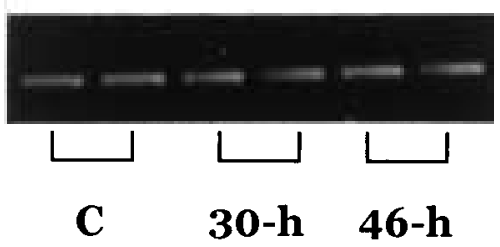

$\beta$-actin

\section{Time of carboxy-PTIO addition}

Fig. 4. LH-induced expression of transcription factor genes c-fos, c-jun and ATF-4 in porcine granulosa cells pretreated with NO scavenger. The porcine granulosa cells $\left(10^{6} /\right.$ dish) were cultured with FSH (0.3 ng/ml); $200 \mu \mathrm{M}$ 2-(4-carboxyphenyl)-4,4,5,5tetramethylimidazoline-1-oxy-3-oxide (carboxyPTIO) was then added to cultures at $30 \mathrm{~h}$ or $46 \mathrm{~h}$ of culture, and cells were cultured until $48 \mathrm{~h}$. The cells were washed and stimulated by LH (100 ng/ $\mathrm{ml}$ ) for $30 \mathrm{~min}$, then total RNA samples were prepared and analyzed by RT-PCR, as described in Materials and Methods. The results presented are obtained from two independent RT-PCR experiments performed for two different mRNA preparations.

its possible role during maturation of granulosa cells prepared from small follicles of porcine ovaries, and found that NO was synthesized at the critical period of cell maturation after FSH stimulation. NO synthesis may have an important role in the differentiation program of granulosa cells, i.e., transformation of the granulosa cell into the luteal cell. eNOS protein is localized in the theca and granulosa cells of gonadotropin-treated immature rats and the developing corpus luteum [9]. Cyclic GMP increase is seen in the in vitro differentiation of rat granulosa cells [16]. In the present study, significant increases of cyclic GMP and NO metabolites (nitrite + nitrate) were also observed near the end of the maturation, suggesting activation of cytosolic guanylate cyclase by the transient synthesis of NO.

We think that the transient generation of NO has an important role in the function of developing
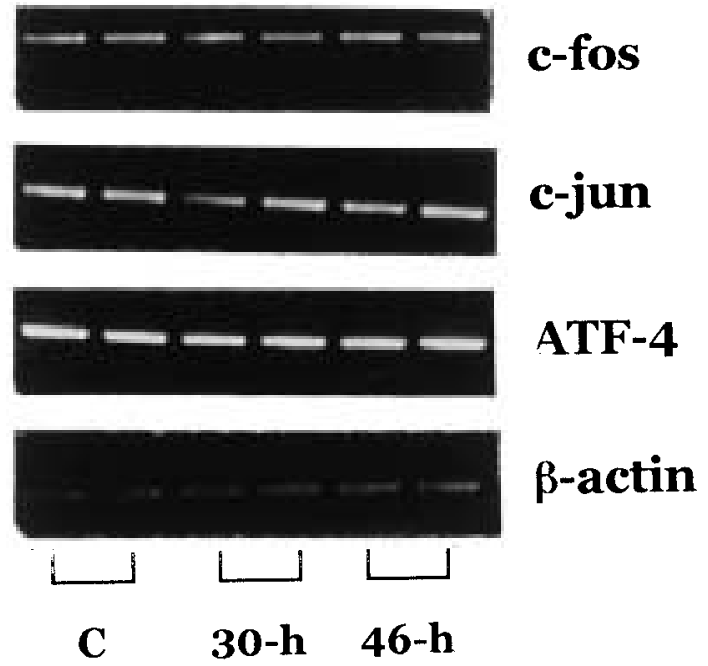

\section{Time of NOC18 addition}

Fig. 5. LH-induced expression of transcription factor genes c-fos, c-jun and ATF-4 in porcine granulosa cells pretreated with NO donor. The porcine granulosa cells $\left(10^{6} /\right.$ dish $)$ were cultured with FSH $(0.3 \mathrm{ng} / \mathrm{ml})$; $50 \mu \mathrm{M} 2,2^{\prime}$-(hydroxynitrosohydrazino)bisethanamine (NOC18) was then added to cultures at $30 \mathrm{~h}$ or $46 \mathrm{~h}$ of culture, and cells were cultured until $48 \mathrm{~h}$. The cells were washed and stimulated by LH $(100 \mathrm{ng} / \mathrm{ml})$ for $30 \mathrm{~min}$, then total RNA samples were prepared and analyzed by RT-PCR, as described in Materials and Methods. The results presented are obtained from two independent RTPCR experiments performed for two different mRNA preparations.

granulosa cells. We previously reported that NO might take part in the regulation of EGF receptor expression in developing rat granulosa cells stimulated by $\mathrm{FSH}$; addition of an NO donor, SNP, stimulated expression of the EGF receptor, whereas carboxy-PTIO (blocking NO action) had an inhibitory effect on the expression [16]. In the present study, NOC18 was used as an NO donor, because it produced NO in a short time, resulting in a marked increase in cyclic GMP synthesis. We theorized that $50 \mu \mathrm{M}$ NOC18 would produce 100 $\mu \mathrm{M} N \mathrm{~N}, 20$ times the NO produced by the cultured cells. When granulosa cells were exposed to $50 \mu \mathrm{M}$ NOC18 during the critical period of NO release $(40-48 \mathrm{~h})$, the progesterone secretion did not decrease after LH stimulation of the cells. In contrast, there are many reports that a high concentration (more than $1 \mathrm{mM}$ ) of NO donors negatively regulates steroidogenesis after exposure 
in the rodent testes [32], human granulosa-luteal cells [17], cultured rat Leydig cells [33], rat luteinized ovarian cells [18], and porcine granulosa cells $[19,20]$. Estradiol secretion from FSHstimulated porcine granulosa cells is suppressed during 2 h-incubation with NOC18 [19]. Another $\mathrm{NO}$ donor, S-nitroso-N-acetylpenicillamine, was reported as having inhibited progesterone secretion from porcine granulosa cells [20]. In these reports, NO donors and gonadotropin were added simultaneously to cell cultures, whereas in our system LH was added after removal of NO donor and the cells were stimulated for $24 \mathrm{~h}$ by LH. NO inhibits the functions of cytochrome P450 enzymes, including the $\mathrm{P} 450$ aromatase, by directly binding to the enzymes $[17,18,34]$. Since NO is a shortlived molecule, the progesterone synthesis might not have been affected by NO remaining in the medium after removal of $\mathrm{NO}$ donor.

However, in porcine granulosa cells exposed to carboxy-PTIO at the critical period of NO release, the progesterone secretion from LH-stimulated granulosa cells decreased to $61 \%$ of control, and cyclic AMP production decreased to about $50 \%$ of control. We paid attention to the expression of immediate early genes such as c-fos, c-jun, and ATF-4 after LH stimulation. After granulosa cells were exposed to carboxy-PTIO or NOC18 during the critical period of $\mathrm{NO}$ release, the cells were stimulated by LH for $30 \mathrm{~min}$, and then the expression of three transcription factor genes was estimated by a semi-quantitative RT-PCR. A significant decrease of c-fos was observed after treatment with carboxy-PTIO at the critical period. In contrast, c-jun expression significantly increased, and ATF-4 expression was not influenced. When carboxy-PTIO ot NOC18 was added after the critical period, however, expression of these transcription factor genes was not significantly altered. Expression of c-fos and junB was reported in PC12 cells 30 min after activation of cytosolic guanylate cyclase by SNP [35]. In porcine granulosa cells, however, LH-stimulated expression of c-fos was not enhanced after a $2 \mathrm{~h}$ incubation with NOC18. Enhancement of c-jun expression was observed after an $18 \mathrm{~h}$ culture with carboxyPTIO. This contradiction is not clear, but is probably due to partially different types of cells.

At present, it is not clear why the expression of c-fos and c-jun was altered after exposure to NO antagonist. Expression of c-fos is regulated through a well-characterized mechanism of phosphorylation of the dimeric transcription factor, CREB or ATF-4 [36], nuclear actions of protein kinase $C[23,24]$ and $\mathrm{Ca}^{2+} /$ calmodulin-dependent protein kinase [37]. Protein kinase A and protein kinase $C$ are essential elements in expression of the genes which are induced by LH in cultured granulosa cells [22]. Changes of c-fos and c-jun expression produced by blocking $\mathrm{NO}$ action might result from alterations in signaling pathways of these protein kinases, and analyses of signaling pathways remain to be investigated. However, the change of the levels of AP-1 factors probably affects expression of several genes related to cell functions.

In conclusion, $\mathrm{NO}$ was released from cultured porcine granulosa cells during the critical period of maturation. NO might have an important role in the progress of granulosa cell differentiation through modulation of LH-induced expression of c-fos and c-jun.

\section{Acknowledgments}

We are grateful to Dr. A. F. Parlow for the supply of ovine FSH and ovine LH through the National Hormone and Pituitary Program. This study was supported by a Grant-in-Aid for Scientific Research (B) No. 09460139 to M-A. H. from the Japanese Ministry of Education, Science and Culture.

\section{References}

1. Bredt DS, Snyder SH. Nitric oxide mediates glutamate-linked enhancement of cGMP levels in the cerebellum. Proc Natl Acad Sci USA 1989; 86: 9030-9033.

2. Kwon NS, Nathan CF, Gilker C, Griffith OW, Matthews DE, Stuehr DJ. L-Citrulline production from L-arginine by macrophage nitric oxide synthase. J Biol Chem 1990; 265: 13442-13445.

3. Palmer RMJ, Moncada S. A novel citrullineforming enzyme implicated in the formation of nitric oxide by vascular endothelial cells. Biochem Biophys Res Commun 1989; 158: 348-353.

4. Stamler JS, Singel DJ, Loscalzo J. Biochemistry of nitric oxide and its redox-activated forms. Science 
1992; 258: 1898-1902.

5. Bredt DS, Hwang PM, Glatt CE, Lowenstein C, Reed RR, Snyder SH. Cloned and expressed nitric oxide synthase structurally resembles cytochrome P-450 reductase. Nature 1991; 351: 714-718.

6. Lamas S, Marsden PA, Li GK, Tempst P, Michel T. Endothelial nitric oxide synthase: molecular cloning and characterization of a distinct constitutive enzyme isoform. Proc Natl Acad Sci USA 1992; 89: 6348-6352.

7. Lowenstein CJ, Glatt CS, Bredt DS, Snyder SH. Cloned and expressed macrophage nitric oxide synthase contrasts with the brain enzyme. Proc Natl Acad Sci USA 1992; 89: 6711-6715.

8. Van Voorhis BJ, Moore K, Strijbos PJL, Nelson S, Baylis SA, Grzybicki D, Weiner CP. Expression and localization of inducible and endothelial nitric oxide synthases in the rat ovary. J Clin Invest 1995; 96: 2719-2726.

9. Jablonka-Shariff A, Olson LM. Hormonal regulation of nitric oxide synthases and their cellspecific expression during follicular development in the rat ovary. Endocrinology 1997; 138: 460-468.

10. Ellman C, Corbett JA, Misko TP, McDaniel M, Beckerman KP. Nitric oxide mediates interleukin1-induced cellular cytotoxicity in the rat ovary: a potential role for nitric oxide in the ovulatory process. J Clin Invest 1993; 92: 3053-3056.

11. Ben-Shlomo I, Kokia E, Jackson MJ, Adashi EY, Payne DW. Interleukin- $\beta$ stimulates nitrite production in the rat ovary: evidence for heterologous cell-cell interaction and for insulinmediated regulation of the inducible isoform of nitric oxide synthase. Biol Reprod 1994; 51: 310-318.

12. Chun S-Y, Eisenhauer KM, Kubo M, Hsueh AJW. Interleukin-1 $\beta$ suppresses apoptosis in rat ovarian follicles by increasing nitric oxide production. Endocrinology 1995; 136: 3120-3127.

13. Shukovski L, Tsafriri T. The involvement of nitric oxide in the ovulatory process in the rat. Endocrinology 1995; 135: 2287-2290.

14. Bonello N, Mckie K, Jasper M, Andrew L, Ross $\mathrm{N}$, Braybon $\mathrm{E}$, Brannstrom $\mathrm{M}$, Norman RJ. Inhibition of nitric oxide: effects on interleukin- $1 \beta$ enhanced ovulation rate, steroid hormone, and ovarian leukocyte distribution at ovulation in the rat. Biol Reprod 1996; 54: 436-445.

15. Yamauchi J, Miyazaki T, Iwasaki S, Kishi I, Kuroshima M, Tei C, Yoshimura Y. Effects of nitric oxide on ovulation and ovarian steroidogenesis and prostaglandin production in the rabbit. Endocrinology 1997; 138: 3630-3637.

16. Hattori M-A, Sakamoto K, Fujihara N, Kojima I. Nitric oxide: a modulator for the epidermal growth factor receptor expression in developing ovarian granulosa cells. Am J Physiol 1996; 270: C812-C818.

17. Van Voorhis BJ, Dunn MS, Snyder GD, Weiner
CP. Nitric oxide: an autocrine regulator of human granulosa-luteal cell steroidogenesis. Endocrinology 1994; 135: 1799-1806.

18. Olson LM, Jones-Burton CM, Jablonka-Shariff A. Nitric oxide decreases estradiol synthesis of rat luteinized ovarian cells: possible role for nitric oxide in functional luteal regression. Endocrinology 1996; 137: 3531-3539.

19. Masuda M, Kubota T, Karnada S, Aso T. Nitric oxide inhibits steroidogenesis in cultured porcine granulosa cells. Mol Hum Reprod 1997; 3: 285-292.

20. Vranova J, Jezova M, Scsukova S, Kolena J. Inhibitory effect of gossypol on basal and luteinization factor-stimulated progesterone synthesis in porcine granulosa cells. Physiol Res 1999; 48: 119-128.

21. Hsueh AJW, Bicsak TA, Jia X-C, Dahl KD, Fauser BCJM, Galway AB, Czekala N, Pavlou SN, Papkoff H, Keene J, Boime I. Granulosa cells as hormone target: the role of biologically active follicle-stimulating hormone in reproduction. Rec Prog Horm Res 1989; 45: 209-273.

22. Richards JS, Fitzpatrick SL, Clemens JW, Morris JK, Alliston T, Sirois J. Ovarian cell differentiation: a cascade of multiple hormones, cellular signals, and regulated genes. Rec Prog Horm Res 1995; 50: 223-254.

23. Doucet JP, Squinto SP, Bazan NG. Fos-jun and the primary genomic response in the nervous system. Possible physiological role and pathophysiological significance. Mol Neurobiol 1990; 4: 27-55.

24. Sheng $\mathbf{M}$, Greenberg ME. The regulation and function of c-fos and other immediate early genes in the nervous system. Neuron 1990; 4: 477-485.

25. Mondschein JS, Smith SA, Hammond JM. Production of insulin-like growth factor binding proteins (IGFBPs) by porcine granulosa cells: identification of IGFBP-2 and -3 and regulation by hormones and growth factors. Endocrinology 1990; 127: 2298-2306.

26. Sato $Y$, Horita $H$, Kurohata $T$, Adachi $H$, Tsukamoto T. Effect of the nitric oxide level in the medial preoptic area on male copulatory behavior in rats. Am J Physiol 1998; 274: R243-R247.

27. Chung H-O, Kato T, Kato Y. Molecular cloning of c-jun and c-fos cDNAs from porcine anterior pituitary and their involvement in gonadotropinreleasing hormone stimulation. Mol Cell Endocrin 1996; 119: 75-82.

28. Kato Y, Koike Y, Ogawa S, Tomizawa K, Hosaka K, Tanaka S, Kato T. Presence of activating transcription factor 4 (ATF4) in porcine anterior pituitary. Mol Cell Endocrin 1999 (in press)

29. Tokunaga K, Taniguchi H, Yoda K, Shimizu M, Sakiyama S. Nucleotide sequence of a full-length cDNA for mouse cytoskeletal $\beta$-actin. Nuc Acid Res 
1986; 14: 2829.

30. Hattori M-A, Ozawa K, Wakabayashi K. Sialic acid moiety is responsible for the charge heterogeneity and the biological potency of rat lutropin. Biochem Biophys Res Commun 1985; 127: 501-508.

31. Akaike T, Yoshida M, Miyamoto $Y$, Sato $K$, Kohno M, Sasamoto K, Miyazaki K, Ueda S, Maeda H. Antagonistic action of imidazolineoxyl $\mathrm{N}$-oxides against endothelium-derived relaxing factor / $\bullet$ NO through a radical reaction. Biochemistry 1993; 32: 827-832.

32. Adams ML, Mock B, Truong R, Cicero TJ. Nitric oxide control of steroidogenesis: endocrine effects of $\mathrm{NG}^{\mathrm{G}}$-nitro-L-arginine and comparisons to alcohol. Life Sci 1992; 50: 35-40.

33. Welch C, Watson ME, Poth M, Hong T, Francis GL. Evidence to suggest nitric oxide is an interstitial regulator of Leydig cell steroidogenesis.
Metab 1995; 44: 234-238.

34. Snyder GD, Holmes RW, Batas JN, Van Voorhis BJ. Nitric oxide inhibits aromatase activity: mechanisms of actions. J Steroid Biochem Mol Biol 1996; 58: 63-69.

35. Haby C, Lisovoski F, Aunis D, Zwiller J. Stimulation of the cyclic GMP pathway by NO induces expression of the immediate early genes cfos and junB in PC12 cells. J Neurochem 1994; 62: 496-501.

36. Meyer TE, Habener JF. Cyclic adenosine 3',5'monophosphate response element binding protein (CREB) and related transcription-activating deoxyribonucleic acid-binding proteins. Endocrine Rev 1993; 14: 269-290.

37. Ransone LJ, Verma IM. Nuclear protooncogenes fos and jun. Ann Rev Cell Biol 1990; 6: 539-557. 